\title{
Planning a Dictionary for Mother Tongue Education: A Conceptual Framework for Gabonese Languages*
}

Blanche Nyangone Assam, Department of Foreign Languages, University of the Western Cape, Bellville, South Africa

(bassam@uwc.ac.za)

\begin{abstract}
The present article is a plea for mother tongue education dictionary projects in Gabonese lexicography. The latter has been in a fast-developing process for the past twenty years and has experienced quite an important crop of dictionary products in such a short time. However, the production of dictionaries for mother tongue education, especially for Gabonese native languages, has been totally neglected. Only a very limited number of projects, which have ever since remained at the level of studies, do exist. This article provides a conceptual plan for mother tongue education dictionary production in Gabonese native languages. It successively suggests an organisation plan and a dictionary conceptualisation plan.
\end{abstract}

Keywords: CONCEPTUALISATION PLAN, DICTIONARIES, MOTHER TONGUE EDUCATION, GABON

Résumé: Planification d'un Dictionnaire pour l'Enseignement en Langue Maternelle: Un Cadre Conceptuel pour les Langues Gabonaises? Le présent article est un plaidoyer pour des projets de dictionnaires en vue de l'enseignement en langue maternelle dans la lexicographie gabonaise. Cette dernière connaît un développement rapide depuis ces vingt dernières années et a vu un nombre assez important de dictionnaires publiés en une période de temps limitée. Cependant, la production des dictionnaires pour l'enseignement en langue maternelle, particulièrement en langues locales gabonaises, est totalement négligée. Seul quelques projets restés depuis au stade d'études existent. Cet article propose un cadre conceptuel pour la production des dictionnaires comme outil d'enseignement en langue maternelle pour les langues locales gabonaises. L'article présente successivement un plan d'organisation et un plan de conceptualisation.

Mots-clés: CONCEPTUALISATION, DictiONNAIRE, ENSEIGNEMENT EN LANGUE MATERNELLE, GABON

\section{Introduction}

This article in the form of a conceptual framework paper comes within the

* This article is based on a chapter of a D.Litt. Dissertation, Dictionaries as Teaching Instruments for Mother-tongue Education: The Case of Fang in Gabon.

Lexikos 27 (AFRILEX-reeks/series 27: 2017): 378-402 
overall plan and intention of introducing Gabonese native mother tongues into the education system of Gabon. The intention has been repeatedly stated by the Gabonese government during the General States Meeting for Education and Training held in Libreville in 1983 (Kwenzi Mikala 1990) and during the General States Meeting for Education, Research and Training-Employment Adequacy held in Libreville in 2010 (République Gabonaise 2010). Since then, a number of research works in the field of linguistics have been undertaken to fulfil such a plan and intention. In this regard, Nzang-Bie (2001: 17) states that one of the priorities of research in linguistics (and related disciplines) within the context of Gabon should be the "introductions of local languages in national education curricula". For Nzang-Bie (2001), who advocates for bilingual or multilingual education in Gabon, this process implies the compilation and production of textbooks and dictionaries not only for bi- or multilingual education but also for mother tongue education in rural areas.

In the field of lexicography, it has been stated that the development of lexicography and dictionary production would certainly contribute to mother tongue education implementation in Gabon (Emejulu 2001 and 2003; Mavoungou 2010). For this purpose, initiatives of pedagogical lexicography for Gabonese languages by Mabika Mbokou (2001 and 2006), Nyangone Assam (2001, 2002 and 2006) and Ella (2002 and 2007) constitute an important contribution to the strategic plan for Gabonese lexicography (Ndinga-Koumba-Binza 2005).

The current article is a follow-up to these enterprises by Mabika Mbokou and Nyangone Assam. Its relevancy is grounded on the fact that no lexicographic project related to mother tongue education has ever been undertaken in Gabon for the past ten years. Thus, the article is an attempt to revamp not only past projects, but also most importantly the whole focus on mother tongue education lexicography in Gabon. The content of the article mainly focuses on Fang as language for illustration and reference.

The planning phase in a lexicographic process can be divided into two distinctive plans, i.e. the organisational plan and the dictionary conceptualisation plan. The former will be presented in section 3 of this article, and the latter in section 4. Prior to these two sections, the article starts with a short rationale.

\section{Bilingual dictionaries for mother tongue education: A case for Gabon}

The making of a dictionary does not start with the defining of words. It is preceded by a great deal of planning. Gouws (1999: 41) argues that the planning of the compilation of a dictionary starts with the planning of the system to be utilised in that specific dictionary. Dictionaries must first be conceived and then written. Planning is the design phase for creating both the text specifications and the way the whole text will be written. Gouws (1999: 41) further maintains that before the lexicographer puts one word on paper in the compilation process, he/she has to be well aware of the precise structure each article should display so that the system can be applied with meticulous care. 
The interest here is the sequence of work to be undertaken for a language, which does not have yet a fully developed standard form. The decision about what dictionary to plan depends largely upon the situation of the language itself and upon the state of its lexicographic treatment. Zgusta (1971) lists the steps that lexicographic planning has to follow: the first step is a very small dictionary concerned primarily with orthographic rules and their application in particular cases of single lexical units.

The next step is a bilingual dictionary in which the target language is the vernacular and the source language is the one used by the specific society in its contact with modern civilisation. In the specific case of Gabon, Gabonese native languages should actually be the target languages and French the source language. However, the fact is that apart from bidirectional dictionaries (e.g. Mickala-Manfoumbi 2004), all recently published Gabonese language dictionaries rather have French as the target language (e.g. Mavoungou and Plumel 2010, Van der Veen and Bodinga-bwa-Bodinga 2002, ILALOK 2008, etc.). This common trend stems from early Gabonese dictionaries compiled by missionaries and colonial administrators (e.g. Biton 1907, Biton and Adam 1969, RapondaWalker 1934, etc.).

Meanwhile, the general situation in Gabon suggests that a bilingual dictionary would be more advantageous. Firstly, it brings a greater number of people into contact with the cultural patterns represented by the foreign language in question and thus increases the number of people for whose activities the development of a standard is necessary. Secondly, such a bilingual dictionary helps more effectively to remove the onomasiological gaps. Certainly, a monolingual dictionary can also try to introduce the necessary terminological problems, but it is difficult to find them there, because they are not generally known. On the contrary, an engineer or a teacher, for example, who knows the technical terms of his/her field of interest very well in French or English and tries to write in such subject in his/her own language, will easily find the necessary expressions in the bilingual dictionary.

Thus, the bilingual dictionary is a more effective tool for this purpose than the monolingual one. It should also not be forgotten that it is difficult and often impossible to couch the definition of lexical meaning, necessary in a monolingual dictionary, in a language without a fully stabilised standard form or that lacks many expressions. The compilation of a monolingual dictionary is meant to empower the speech community and that there is no sense in starting with a multi-volume dictionary similar to the Oxford English dictionary for languages without any dictionaries. They first need other dictionaries because a multivolume dictionary will take many decades if not centuries to complete and, during that time, they will still be without any communicative assistance. Once again, the needs and the situation of a specific speech community must guide the process.

This article intends to make a case for developing bilingualized school dictionaries that will help in mother tongue education. The acquisition of both French and a Gabonese native language at this level of education is essential and 
affect the rest of these learners' lives. It gives them a well-balanced perspective of both languages and cultures, they have the opportunity to develop into individuals who know their identity as Gabonese mother tongue speakers, but who are also exposed to the global world through an international language.

\section{The organisational plan}

The organisational plan takes into account all the planning around the project before anything has been done. It can be seen as the business plan of the lexicographic process. Gouws (2001: 65) indicates that the organisational plan is a basic and compulsory component of every lexicographic process. It is primarily directed at the logistics of the project and all the managerial aspects. This is essential for the success of any dictionary project, and the logistic and the managerial infrastructure must precede any editorial work.

Lexicography is a costly activity. It is rather infrequent that phenomenon lexicographic activities are turned into self-supporting undertakings. The usual situation is that funds must be found to finance the project. In any case, when negotiating financial support and when submitting plans, the lexicographer should be very careful in his/her estimate of both the necessary time and the money. In Gabon, language-related research projects receive funding from government public institutions, foreign diplomatic representations or individual benefactors. Most of the latter are politicians or former politicians who wish to have their language and culture in the process of development. The prominent illustration of this situation is given by the Pove language, which has had two dictionaries and a grammar published in the past ten years by MickalaManfoumbi (2004, 2012 and 2013). Mickala-Manfoumbi (2004: 9) states that his research on the Pove language was personally funded by Mr. Guy Nzouba Ndama ${ }^{1}$, a mother tongue speaker of the language.

For mother tongue education lexicography projects, it is believed that the same current funding schemes will be followed. However, it is advisable that international funding should also be searched and applied for. In addition, most academic institutions receive public funding annually for their regular operations. These institutions should also consider supporting lexicography research projects that are undertaken by their respective research units.

Furthermore, the lexicographer's greatest struggle is the struggle against time. Zgusta (1971: 348) states: "I certainly do not know all the lexicographic projects past and present; but of those I know not a single one was finished in the time and for the money originally planned". Suggesting a definite proposal for the issue of time in the specific case of Gabon in terms of dictionary projects would not be an easy task. As a matter of fact, there would hardly be better suggestion other than to have an important number of workers in a single project. In addition, this implies an increase of funding, because not all staff in a dictionary project would agree to work for free intensively in a limited space of time.

Nowadays, lexicographic projects carried out by a single person result in 
smaller dictionaries, apart from a few exceptional cases. The usual situation is that there is a staff, of which the most important members are the editors or the sub-editors grouped around one or two chief editors. In Gabon, where there is no research unit specifically devoted to lexicography, the need for lexicographic projects coincide with the need for establishing lexicography units (Ndinga-Koumba-Binza et al. 2017). For that purpose, this study will refer to the framework for the planning of a lexicographic project suggested by Van Schalkwyk (1999). In the strategic planning of the Bureau of the WAT, Van Schalkwyk stresses nine steps for good and efficient planning of a lexicographic project:

1. Mission statement

2. Areas of strategic focus

3. Description of the situation

3.1 Internal environment

3.2 External environment

4. Analysis of the environment

4.1 Weak points (constraining factors) in the internal environment

4.2 Strong points (supporting factors) in the internal environment

5. Environmental tendencies

5.1 Threats (constraining factors) in the external environment

5.2 Opportunities (facilitating factors) in the external environment

6. Scenario

7. Assumptions regarding the future strategic position (FSP)

8. Objectives

8.1 Long-term objectives

8.2 Medium term objectives

8.3 Strategic aims

9. Plan of action

Once it is decided, what kind of dictionary it should be and what its scope should be, and especially once the target user of the dictionary and his/her needs are known, a mission statement can be formulated. The organisational plan of a dictionary project cannot start without first determining one aspect that has been neglected in so many dictionaries, but which forms an integral part of the organisational plan. This aspect is the identification and formulation of the genuine purpose of the intended dictionary. Gouws (2001: 65) emphasises that it is an exercise of extreme importance to ensure a sound theoretical point of departure for the compilation process. 


\subsection{The genuine purpose and target users group}

In order to be a functional instrument, a planned dictionary has to fulfil the purpose of empowering the learners in their language acquisition endeavour. Wiegand (1998) refers to this purpose as the genuine purpose. Gouws (2001: 66) emphasises the importance of including a clear and unambiguous exposition of the genuine purpose of the dictionary to be compiled in the organisational plan of a dictionary project. According to Gouws (2001: 66), the genuine purpose of a dictionary is co-determined by, among others, its typological nature and its intended target user group.

The target user group of Gabonese pedagogical lexicography dictionaries will primarily be the learners in primary schools, most of which will be in the process of learning their mother tongues. Adults participating in literacy programmes may also find interest in such kind of dictionaries. After an assessment of the user group's needs and reference skills, the choice of the typological nature of an intended school dictionary of a Gabonese language is a bilingualized dictionary, which has features of both monolingual dictionary and a bilingual dictionary.

Gouws (2001: 66) also points out that the first dictionaries to be compiled for a specific language purpose are usually either desk or standard bilingual or monolingual dictionaries. The genuine purpose of such dictionaries is to transfer, by means of lexical data, information regarding the set of lexical items included as treatment units in order to ensure the linguistic empowerment of the target user.

The bilingualized school dictionary will be produced so that the learner who uses the dictionary in a context of learning his mother tongue will have an instrument to assist him in achieving a successful dictionary consultation procedure by reaching the goals that motivated the search. In this case, the learner finds linguistic information as well as knowledge information that enable him to learn about the cultural aspects of his/her mother tongue. This genuine purpose of the intended school dictionary has major implications for the dictionary conceptualisation plan because of its direct impact on the structure and contents of the dictionary articles and the data distribution pattern. In agreement with Gouws (2001), the formulation of the genuine purpose of a dictionary can be regarded as a response to the needs of the intended target users, the needs of the learners here are the motivation behind any decision regarding the typological choice, as well as the structure, contents and the presentation of the intended bilingualized school dictionary.

The organisational plan of the project has to make provision for managerial infrastructure able to cope with the compilation of this school dictionary as it fits the requirement implied and identified by its genuine purpose. The organisational plan of the future bilingualized school dictionary starts with the mission statement. It introduces the dictionary plan for all managerial aspects. 


\subsection{Mission statement}

Formulating the mission statement of a project or an enterprise comprises identifying its aim and task in such a way that the nature of the work clearly emerges. The aim of this project is to compile dictionaries, within lexicographic units in Gabonese languages in order to serve indigenous languages and the language users. The line of function of that lexicographic unit will be to compile, as soon as possible, pedagogical dictionaries for the mother tongue education in primary schools and for adult literacy programmes. This line of function will be supplemented by the following functions:

(i) To endeavour to bring about appropriate lexicographic products for the different languages of Gabon;

(ii) To promote national languages through mother tongue education;

(iii) To empower national languages speakers through literacy campaigns via their respective mother tongues;

(iv) To raise the general level of lexicography in Gabon by cooperation with external dictionary projects, e.g. the Woordeboek van die Afrikaanse Taal (Dictionary of the Afrikaans Language, South Africa).

(v) To actively address the imbalances by training and generating work; and

(vi) To endeavour to foster quality and a unity of character, and to cater for the needs of the user in all its activities and products.

\subsection{Areas of strategic focus and language data collection}

Two essential questions need to be answered: are the right things being done? Are the right things being done right? The answers enable the lexicographic team to consider carefully those areas of the project in which it needs to succeed if it is to remain true to its aims. Such an analysis yields the following areas of performance: language data collection, editorial processing, printing and layout of the dictionary, marketing and research. The nature and the extent of the lexicographic project determine whether all these areas will be applicable. However, all the performances areas of the lexicographer are incorporated into the planning of the project. Further analysis of each of these performance areas is necessary in order to have a precise indication of their content.

This article will not discuss all these areas but it gives a view on the language data collection. Language data collection involves the excerpting of actual speech material from written sources and spoken sources. The selection, sorting, control integration, safekeeping and computerisation of the material are all part of this performance area. A language data collection policy will be needed to ensure that the collection of data proceeds purposefully. This policy ensure that a corpus is constructed for the project. The construction of a database is a costly and time-consuming task. For this reason, it is necessary to 
determine in advance, what is to be collected and how it should be collected. The possibility of utilising an existing corpus is an alternative to an own corpus. For instance, in the case of Fang, a French corpus could be used because of the lack of terminological items for certain fields. However, no dictionary project should be without an authoritative corpus.

One possibility for obtaining or compiling an authoritative corpus for Fang would be the amalgamation of existing small corpora, i.e. those assembled by Afane-Otsaga (2004), Nyangone Assam (2006), Ella (2007) and Ekwa Ebanega (2007). This amalgamation will have certain advantages such as

(i) producing a bigger corpus for the Fang language,

(ii) the possibility to produce various dictionaries of different types from one single corpus, and

(iii) the possibility of regular improvement and additions into the corpus.

The compilation of the Fang amalgamated corpus will to learn from the experiences of the YCY corpus (Ndinga-Koumba-Binza and Mabika Mbokou 2010), a common wordlist including at least 100000 most frequently used similar words of three related languages, i.e. Yipunu, Civili and Yilumbu. The corpus was compiled from various existing dictionaries in the three languages as well as from a number of existing different corpora, i.e. Mabika Mbokou (2006), Mihindou (2006), Tomba Moussavou (2007) and Soami (2010) for Yipunu; Blanchon (1990), Mabika Mbokou (1999), Ndinga-Koumba-Binza (2000 and 2008), Loembe (2005) and Tele-Pemba (2009) for Civili; and Emejulu and Pambo (1990), Mavoungou (2000 and 2002), Mboumba (2009), Saphou-Bivigat (2010) and Mavoungou and Plumel (2010) for Yilumbu.

Amalgamated corpora of this kind can be made for various Gabonese languages on the basis of the groupings of Gabonese languages by Kwenzi Mikala (1998) into language-units. According to Ndinga-Koumba-Binza (2017), each Kwenzi Mikala's language-unit can be divided into sub-groups based on lexical similarities and mutual intelligibility.

Each lexicographic team would have also to consider Gabonese languages actually still unwritten languages. Therefore, the collection of data will follow the collection criteria for unwritten languages as indicated by Singh (1982: 88). He states that for unwritten languages the data collected according to the field method with the help of informants. The criteria for the selection of informants, their age, sex, cultural and psychological qualities like intelligence, memory, alertness, patience, honesty, dependability, cheerfulness, etc. must be considered.

The fieldworker should approach and deal with the informant in a way that will elicit as much data as required without either causing annoyance to the informant or antagonism in him/her. This will ensure faithful and proper elicitation of the proper language data. That is why the speech community must be involved and kept enthusiastic about a dictionary in their language. For instance, in Gabon, the Fang speech community is commonly known to be 
very enthusiastic about their language. The number of informants to be employed depends on the scope and the type of dictionary.

If all the regional varieties of the language are to be included, informants should be selected from all regions, in order to ensure optimum data, it is advisable to select more than one informant for every variety. This would also help on checking and rechecking the data. In order to elicit lexical units of as many varied types as possible, it would be advisable to select from all the following groups: men and women; people of all ages; people belonging to different economic and social groups.

Many typical items common among women may not be elicited from male informants and vice versa. Many unwritten languages are fast coming under the influence of some other languages regarding modernisation and technology. As a result, new lexical items are introduced in the stock of the languages. For instance, in Fang, there is an equivalence for the French lexical item avion (aeroplane) and there are many other lexical items, which the older generation were familiar with. The younger generation has adopted the borrowed lexical item, which leads to a general loss of older lexical items in the language. Only the older generation knows many of the lexical units, which presently have a low usage frequency.

Therefore, the older informants would be useful for providing lexical units of the type mentioned above. The younger generation informants would be equally useful for providing new words introduced into the language. The representation from different social groups will ensure the inclusion of words from those groups. For the preparation of a dictionary of an unwritten language, the lexicographic team or the lexicographer should have knowledge of the life and culture of the speech community. For eliciting words in an unwritten language, word lists of especially a modern language lie French or English might be utilised (Zgusta 1971). Nevertheless, in making use of word list there are limitations to be considered.

The list may contain a good number of lexical items that are quite unknown, or even irrelevant, to native language situations. The general response to enquiries about such items is either that the informant gives generic words for specific objects or tries to coin some equivalents. Some of the newly coined lexical items are very artificial. Their artificiality can be tested by getting them checked with other speakers of the language. In some cases, the native speaker confesses total ignorance of a lexical item. There is a total unawareness of the local environment and objects in such lists.

How can a lexicographer ensure maximum elicitation for a dictionary of such a language Singh (1982: 91) suggests that a list of basic words belonging to different semantic domain and grammatical classes may be tentatively prepared for elicitation of data for unwritten languages the semantic domains include for instance: nature, earth, sky, natural events, geographical and astronomical items, directions, winds, weather, season, etc. mankind, sex, family, relationship, body parts, bodily functions and conditions, diseases and cure. 
Clothing and personal adornments; food and drink, methods of preparation; dwelling, part of the house and furniture, etc. cooking utensils, tools, weapons, etc. flora and fauna (including part of animal anatomy, diseases, cures, etc.); occupations and professions, equipment, rituals and customs connected with them; road and transport; sense of perception; emotions, temperamental, moral and aesthetic (including insults, curses etc.); government, war, laws; religion; education; games and amusement, entertainment, music, dance, dram; metals; numerals and systems of enumeration; measurement of time, space volume, weight, quantity; functions words including classifiers; fairs, festival, customs, beliefs, etc. verbs: physical activity, instrument verbs, verbs of fighting, music verb, motion verbs, occupational verbs, culinary verbs, cosmetic verbs, communicative verbs, stationary verbs, sensory verbs, emotion verbs, other verbs.

This list is not exhaustive. It might be treated as a sort of referee point and related words on the semantic domain might be elicited based on this list. For example, while collection word about agriculture, words about the different agricultural products, the sowing and harvesting time, rituals and ceremonies connected with them, names of the different parts at different times of growth of these products and the verbs connected with different actions connected with them might be elicited. The data collected by using word list might not be adequate, especially from a semantic view. According to Samarin (1967: 208): "the chief failure of the field dictionary is that it indicates not so much the meaning of word, but the fact that they exist. They do not define, they document". The data for a dictionary collected from the word list should be supplemented by the data from different types of discourses, some of which are listed as follow (Samarin 1967: 2018):

(i) Narration: eyewitness account, reminiscences and instructions on how to perform certain tasks or how to get to certain destinations.

(ii) Conversation: arguments, dialogues about 'where you have been'.

(iii) Songs: lullabies, dirges, dance songs. Folk tales: legends, how things come to be, amusing stories, proverbs and riddles.

(iv) Names: personal, topographic, village, pseudo-onomatopoetic calls of animals or birds.

The collection of data from unwritten languages still has many problems. One of the most important problems is the segmentation and identification of a word from the phonetic continuum of texts, in written languages, which have a tradition of grammar; there are certain devices and fixed criteria to identify a word. According to Singh (1982: 94), "a word in written languages is generally identified as a meaningful unit, a cluster of sounds or letters written between spaces, or with potential pauses. In unwritten languages, there is no such device. The lexicographer has to analyse the data, to make a grammatical analysis of the language, and then to fix the word and the lexicographic unit". The collection of material from oral and written sources will serve the building of a corpus. The corpus for the intended 
dictionary has to take into account the needs of the target group, learners in school. The learners need text reception and text production skills in the language being learned. A more comprehensive representation of data and additional guidance is necessary.

\subsection{Description of the situation}

It is important for proper planning to negotiate the situation in which a project finds itself. The internal and external environment determine this situation. The internal environment of a project comprises everything that is within the control of the project. All other matters that can influence the activities of the project but fall outside its control are regarded as part of the external environment, for example, the politico-economic circumstances prevailing in the country. A sound grasp of the external environment makes those involved more sensitive to the milieu in which they operate.

In the internal environment of this project, the collection and selection of language data, the editorial processing and layout depend on the lexicographic team. When the planning is thorough, the task becomes much easier and less time consuming. The finance and support services depend on the external environment.

The nature and extent of the reference and research work that the lexicographic team undertakes must be considered during the planning phase. A lexicographer's efficiency is compromised in the absence of reference material and library facilities. If these cannot be utilised elsewhere, they will have to be made available. The purchase and maintenance of office equipment, and computers and software requires large capital expenditures, which must be considered thoroughly during this planning phase.

In fact, all supplies needed for a lexicographic project must be calculated and taken into account so that it can be incorporated into the budget.

\subsection{Analysis of the environment}

The success of a project or enterprise depends largely on whether those involved are capable of identifying and acting upon the weak as well as the strong points in the internal environment. The weak points of a project increase its vulnerability in a changing world. If the project is aware of them, all the mechanisms can be put into operation to soften their effect as far as possible or even to eliminate them. The strong points of a project in the internal environment present the project with the opportunity to take proactive steps to ensure success.

The weak point of this project will be the lack of trained people to carry out the fieldwork for the language data collection. It is important to involve linguists and others interested in language matters in the project. Of course, the 
language speech community must be kept enthusiastic about their language and the project. Sound metalexicographic training of the team must be planned and encouraged. This will ensure that the Fang speaking community will get involved in Fang lexicography, the Punu speaking community in the Punu lexicography, the Nzebi speaking community in the Nzebi lexicography and dictionary production, etc.

The strong point is that the government supports the project entirely. It will create jobs and promote the local languages. It will introduce the culture of dictionary use among the young and the older generation.

\subsection{Environment tendencies}

Threats or constraining factors in the external environment must be identified, analysed and overcome, because it is in this way that the risks to which a project is exposed are reduced. A sound grasp and utilisation of the opportunities or facilitations factors in the external environment can assist in neutralising the constraining factors.

In a mother tongue education dictionary project, the only great threat could be a possible change in the politico-economic situation of Gabon because it is a government project and they will supply all financial and material support needed. There is also the threat that decisions to be taken by linguists and lexicographical experts regarding language issues become bureaucratic and political. An awareness of the endangered situation of local languages will prevent such turn.

\subsection{Scenario}

The aim of a scenario in a mother tongue education dictionary project would to outline a potential future in which the project must function with possible linguistic changes taken into account. This can give an indication of the challenges awaiting the project, but it also give an indication of the impact that the decision currently taken will have in future. A scenario can help the decision makers to evaluate the effect their decision critically.

In five years' perhaps, the language policy would not have changed because French will remain the sole official language. There will however be other changes because the government has recognised the necessity of mother tongue education. Acting on this awareness, it has initiated the training of teachers at university level for mother tongue education. This teaching section will be functional in five years' time. This means that it invests in the preparation of pedagogical books and dictionaries through the Ministry of Education. The training of translators, interpreters and broadcasters will also take place to anticipate the various needs of the Ministry of Communication and parliament. The direct and evident manifestation will be the compilation of language dic- 
tionaries alongside other pedagogical material and textbooks. The establishment of lexicographic units is therefore a matter of urgency in the future. The development of lexicography in Gabon depends on the implementation by government of these programmes.

\subsection{Assumptions regarding the future strategic position}

Planning is always directed towards the future and, since the future is not known, planning involves working with assumptions. These assumptions are supported by the achievements of the project, by its current situation and level of development, as well as by the vision of those involved.

It can be envisaged that in the next five years for a mother tongue education dictionary project starting at the current period, the project would have trained lexicographers to start working. The collection of language data and computerisation should be advanced. There should be experienced linguists, language practitioners as well as any other necessary language experts.

\section{$3.9 \quad$ Objectives}

In order to carry out its functions efficiently and effectively, to strive for excellence in living up to its stated mission, and to remain on tract and not to lose its vision, an enterprise or project must work according to explicitly formulated aims and objectives.

The long-term objective of a mother tongue education dictionary project is to provide Gabonese languages with dictionaries to revitalise languages that are now endangered.

The medium-term objective will be to build a corpus of the main languages that will serve for dictionaries. The strategic aim is to start the establishment of a lexicographic unit.

\subsection{Plan of action}

Planning is seen as a team effort and is of no value if it cannot be brought to fruition. Efficient planning and management of goals keep the time and money expenditures of a lexicographic project within bounds. An estimation of the time and capital needed for a lexicographic project demands extensive preparation. The planning of a lexicographic project is practically impossible without extensive lexicographic experience. This issue is more and more being solved with the constant training of Gabonese lexicographers at university level. Nyangone Assam et al. (2016: 180) reports that "training is the one aspect where the strategic planning of Gabonese lexicography has been quite successful". Gabon has been for the past twenty years in the process of raising a generation of qualified and experienced lexicographers. 
When lexicographic planning is carried out, the most important things to bear in mind are the specific lexicographic needs of the given language and its dictionary users. These needs will lead the decision makers to adapt the necessary organisational approach. In the planning of any kind of dictionary, the emphasis should always be on the needs of the intended users. This can be illustrated with the specific case of Yilumbu for which the need was twofold, i.e. first the language has never had a dictionary previously, and second the language is under great influence attacks from the neighbouring languages which are Civili in the town of Mayumba, Yipunu in the town of MoulenguiBinza and in Dousségoussou region, and Varama and Nkomi in the towns of Gamba and Sette-Cama (Mavoungou 2002). The metalexicographical planning conducted by Mavoungou (2002 and 2012) resulted successively in a general bilingual translation dictionary (Mavoungou and Plumel 2010) and in a translation dictionary of idiomatic phrases (Mavoungou and Ndinga-KoumbaBinza, submitted).

Furthermore, during the planning of a dictionary of a not yet stabilised language, the lexicographer must make up his/her mind about which policy to follow. It is during this phase that the lexicographer has to negotiate some important issues, e.g. the functions, structure and contents of the dictionary. $\mathrm{He} / \mathrm{she}$ decides which variety of the language will be used in the dictionary. While doing so, the users' needs should guide his/her choices on the lexical items to be included or not. Considering this case, the first target group of users will be schoolchildren, which implies a need for the core vocabulary. The context of communication and the vocabulary in daily use will be adequate for learners.

For the Fang language for instance, Afane-Otsaga (2004, 2010a and 2010b) has been insisting that for the stabilisation and/or standardisation of Fang, the variety of the language spoken in Oyem (capital city of the Woleu-Ntem province $^{2}$ in the north of Gabon)

\section{The dictionary conceptualisation plan}

The dictionary conceptualisation plan takes into account all the decisions made about the compilation process. It can be considered as the practical side of the lexicographic process. According to Wiegand (1998: 151), the dictionary conceptualisation plan can be divided into five subdivisions: the general preparation phase, the material acquisition phase, the material preparation phase, the material-processing phase and the publishing phase.

Gouws (2001: 65) points out that the organisational plan can be regarded as a model formal the primary lexicographic process for that dictionary. It concerns all the managerial aspects dealt with previously in the present study. He suggests that the dictionary conceptualisation plan represents a model for the secondary lexicographic process of a specific dictionary. The genuine purpose of the future bilingualized school dictionary is to enable the learners to achieve 
successful retrieval of information in the dictionary consultation procedure.

It aims to give them a practical instrument to help in the acquisition of their mother tongue via French as the source language. The needs and the reference skills of the target user group determines the genuine purpose of the dictionary, which is therefore the basis for the dictionary conceptualisation plan. The conceptualisation plan for a bilingualized school dictionary is presented according to the following aspects identified by Wiegand (1998).

\subsection{The general preparation phase}

The general presentation phase of the dictionary conceptualisation plan lays the foundation for the structure, contents and presentation of the final product. Gouws (2001: 68) identifies three issues to tackle in the general preparation phase. The compilation of a lexicographic instruction book or a lexicographic style guide is the first assignment of the team members. The second assignment to achieve is the microstructural programme of the dictionary. A third issue to be dealt with in the general preparation phase is the identification, establishment, nature, extent and description of a dictionary basis.

\subsubsection{The instruction book for or style guide}

The style guide includes instructions for the making of a dictionary. According to Bergenholtz (1990), the lexicographic style guide should contain a comprehensive description of a system applied in the dictionary. The editorial process will be much more efficient with the setting up of a style guide, which is a set of generalisations with accompanying illustrations from the envisaged dictionary. It is a set of instructions showing the order of components, typological presentation and input instructions for the database. The style guide is needed to ensure confidence and consistency on the part of the lexicographer, i.e. to ensure a uniform character and prevent deviation from the rules.

It is a learnable system for new lexicographers and contains detailed guidelines on how to treat each type of data category, how to treat difficult or prominent semantic and grammatical phenomena (homophony, polysemy, etc.) and other important data, for instance: spelling convention; data on pronunciation; parts of speech; cross-references, list of labels, list of editorial abbreviations; definition or translation equivalent, example material, homonymy, polysemy and synonymy; treatment of sensitive lexical items; treatment of cultural data.

General editorial principles have to be established. A rough style guide of data categories abstracted from samples of dictionary articles should be used for consistency by compiling computerised system. It is important to refine sample entries and the style guide to reflect changes during the compilation of the dictionary. A frequent update of the style guide is required. The computer- 
ised system design helps to root out inconsistencies in the style guide, especially in the treatment of senses and sub-senses. It makes it easier to apply the style guide consistently, especially with regard to the ordering of data and the formatting of dictionaries articles.

Bergenholtz (1990) includes more of the typical issues to be dealt with an instruction book, for example the lemmatisation process (with reference to, for instance, the influence of an initial capital letter, diacritics, the order of the word and stem forms), the use of typographical and non-typographical markers in the articles, the making of different senses of a lemma, the use of abbreviations in the metalanguage of the dictionary, and the positioning and marking of new search zones in the article.

A style guide has to be developed. It shall cover all aspects of lexicography relevant to the dictionary to be compiled. It should preferably be an alphabetically arranged reference guide for making the manuscript, starting, for instance, with the abbreviations an editor may use and ending with the treatment of verbs. It should discuss the different kinds of definitions and when to use them, synonymy and semantic opposition, polysemy and homophony, the ordering of senses, and the treatment of gender and derogatory items. The style guide covers in detail in all the types of data that need to be presented in the envisaged dictionary. It has to be indicated in a consistent pattern so that it facilitates the work of the compilers. It should give clear guidance on labelling and the presentation of information. Typography and punctuation should be discussed in detail, for instance that all lemmas should be in bold print and grammatical data like parts of speech and plurals should be in italics.

The development of a style guide is essential as it serves as a training manual for new editors with little or no lexicographical training; it ensures that every editor makes the manuscript in the same way and that the dictionary eventually has a uniform character. It also prevents gradual deviation from the treatment of raw material originally decided on.

\subsubsection{The microstructural programme}

According to Gouws (2001: 68), the microstructural programme is another important issue in the general preparation phase that needs to receive attention. He states that at a very early stage of the lexicographic process, the team members should know the microstructural programme thoroughly. The microstructural programme involves the different data categories to be included in the treatment of the lemmata and the typical article slots allocated to these categories. It assists the team members to determine the quantitative extent of the dictionary. It enables team members to ensure a functional space budget because a dictionary always has space limitation and an early indication of the microstructural programmes provides good space management. Gouws (2001: 68) points out that a further value of the early identification of the microstructural programme is that it assists the lexicographers during the early phases of the 
compilation process to focus on those data categories that will be included in the dictionary.

With regard to Fang, Nyangone Assam (2006: 85) indicates that in response to the genuine purpose and the functions determined by the needs of the users, the French-Fang bilingualized school dictionary would present an integrated microstructure. Gouws (2001: 87) defines integrated microstructures as one presenting a relation of direct addressing between a paraphrase of meaning/translation equivalent and its co-text entry/entries. It means that each paraphrase of meaning/translation equivalent is immediately followed, within the same sub-comment on semantics, by the co-text entry illustrating the typical usage of lexical item in question.

An integrated microstructure ideally suits this bilingualized dictionary because it makes the appropriate interpretation of the contents of the subcomment on semantics for the user very easy. Especially in the treatment of a lexical item with many polysemous senses, the direct relation between co-text entry and paraphrase of meaning/translation equivalent ensures an optimal retrieval of information. It decreases text condensation because no other paraphrases of meaning/translation equivalences come between a given paraphrase of meaning/translation equivalent and its co-text entry. This is illustrated by the example below adapted from Nyangone Assam (2006: 86):

Abum [ábùm] nom. Pluriel mebum (Var: amum, memum)

1. Ventre, abdomen. Makon abum, mawok abum, j'ai mal au ventre.

2. Mère. Bine abum avor, nous sommes issus de la même mère.

3. Grossesse. E minga nyi ane abum, Cette femme est enceinte.

The dictionary article above is an example of the treatment of a lemma in the integrated microstructure of the bilingualized school dictionary. The lemma abum (stomach) has polysemous senses: 1 . (stomach) the translation equivalents in French are given followed by the example sentences in Fang then in French to illustrate the usage of lemma in this specific sense. It is the same for the last two senses. There is a direct relationship between the translation equivalents and the co-text entry.

In the above article, the data categories that are included in the microstructure are the following:

(i) Comment on form: an indication of the pronunciation is given for each lemma so that the learners will be helped with the pronunciation of each lemma. Pronunciation is given in the phonetic transcription and the tones for Fang lemmata will be included to give learners a solid basis for pronunciation. One of the main functions of the bilingualized school dictionary is to enable learners to read and write in their mother tongue Fang. The class of the lemma, part of speech, is indicated for the learners and they will know whether the lemma is a noun, a verb, an adverb, a pronoun, etc. the morphological data on the lemma, whether it is the plural or 
diminutive forms, is also indicated when necessary to give earners a thorough perspective of the lemma treated. Fang is a language with different variants and the treatment makes provision for an indication of the variants when they occur.

(ii) Comment on semantics: a translation equivalent and a definition are given followed by the example sentences in the language pair French and Fang. Idioms will be presented and treated as sub-lemmata treatment, but very few clusters will appear in the microstructure. Only those that are part of the learners' core language and have a high frequency of usage as indicated by the corpus will be given treatment as lemma. Collocations will not be treated as units, but each component, the base and the collocator of the combination, will be treated under its alphabet stretch. The collocations will be treated as illustrated examples in both the articles representing the base and the collocutor.

\subsubsection{The dictionary basis}

According to Wiegand (1998: 139), a dictionary basis can be described as the total of the source language data for the specific lexicographic process. This includes all the possible sources, which accommodate such material, as well as informants and mother tongue speakers of the language who can assist the editorial staff in the building up of a material collection. The dictionary basis of the planned school dictionary will be compiled from three types of sources. Wiegand (1998: 139) shows that the dictionary basis of a general monolingual or bilingual dictionary can be compiled from three sources. The primary sources of the dictionary basis will be all written material that reflects typical communication situations. The secondary sources are all available dictionaries in the specific language. The tertiary sources involve all other linguistic material that can be used, for example linguistic monographs, papers and grammars.

The dictionary basis of the school dictionary should be compiled for French and Gabonese native languages. As far as French is concerned, all three sources are available and abundant. The primary sources, written material that reflects typical communication are available since it is the language of wider communication and of instruction in Gabon. These include schoolbooks, storybooks, textbooks and all other material used in the curriculum at this level. Gabonese novels, poetry books and any creative writings in French can also serve as primary sources.

The secondary sources, available dictionaries in French, are abundant and will be easy to collect, but the collection of material must be guided by the purpose and functions of the envisaged bilingualized school dictionary. Gabonese French lexicography has also been in a developing process with a few Gabonese French dictionaries that have been published (Nyangone Assam et al. 2016). These dictionaries can also contribute as secondary sources. 
The tertiary sources are the other linguistic material, particularly grammars, available in French for the primary education level. It is important to emphasise that cooperation within the team that included teachers and educational experts at the primary level is crucial.

Compiling the dictionary basis for a Gabonese native language is not as unproblematic as it is for French. All Gabonese native languages are unwritten and less-resourced languages with limited amount of written sources. Gouws (2001: 68) indicates that, although the primary sources will usually be texts, the dictionary basis of a dictionary compiled for a language with a strong oral tradition can also use speech recordings of the orature as primary sources.

\subsection{Editorial processing}

Editorial processing is one of the line functions of all dictionary projects, and includes the systematisation of linguistic material and the production of manuscripts and dictionary texts. The question as to what material should be included and what should be excluded is fundamental to the lexicographic team. This question will be answered in the light of the kind of dictionary that is compiled as well as its scope. The inclusion policy needs to cater for the macro- as well as microstructure of the dictionary. It must be determined which elements become lemmas and what lexicographic data should be supplied for each of these elements. Gouws (1997: 42) points out the importance of efficient well-planned editorial processing:

The macrostructure represents the lexicon and this selection may not be on a random basis. It is important that the compilation of any dictionary be dominated by well-defined principles regarding the collection and selection of lexicon items. The lemmata have to be drawn from a representative corpus of that specific language and a vital part of the planning of any dictionary is the development of a corpus. The successful retrieval of information in any dictionary often depends on an unimpeded access to the needed lemma sign.

Depending on the size of the editorial staff, one or more editors should revise the work of the others. Amongst the others, he/she must see it that the editorial manual is follower correctly to ensure that the dictionary has a uniform character. He/she has to look at the data and decide whether it has been interpreted correctly. Firstly, he/she must judge whether the inclusion of the lemma complies with the policy. He/she must check the pronunciation indicated, the grammatical information supplied, and so forth. He/she must ascertain whether the information in the definition is correct, and whether it has been formulated clearly and unambiguously. He/she has to check all the cross-references to ensure that the dictionary is reliable and closely-knit unit.

Fortunately, editing is only about checking up and correcting mistakes. It is also of invaluable help to younger colleagues who learn a tremendous amount from the changes suggested. In the beginning, the changes should always be discussed with the younger colleagues because this promotes the learning process. 


\subsection{A dictionary-making system and customisation of computer software}

The corpus should be the point of departure from which the lexicographic team will abstract items to include and exclude from the pedagogical dictionaries that are needed for a specific dictionary project. However, it is vital for the project to have an authoritative database, which would also be utilised for dictionary projects.

Lexicographers' knowledge of dictionary-making systems could ensure that they gain as much as possible from systems developed from them. In order to make their contributions count in the design of dictionary-making systems, according to Harteveld and Louw (2004), they should consider the following:

1. Speed: The system should speed up the dictionary-making process as much as possible.

2. User-friendliness: The editor must find the use of the system and the editing of the dictionary entries on the system simple and sufficient.

3. Flexibility/adaptability: It should be easy to modify the system to suit individual or changing needs

4. Language support: All characters required by the lexicographer should be available.

5. Access to language data: Language data resources should be easily, if not simultaneously, accessible on the workstation used for editing.

6. Interface: Queries of manuscript data as well as other language resources should be possible by means of a simple interface.

7. Group work/Networking/Internet: It should be possible to be able to communicate, to exchange and to share material quickly and over long distances.

8. Compatibility with other/external data: The system should use file and data formats, which make exchange, sharing, and incorporation with other data simple and accurate.

9. Multiple output formats (electronic, printed): The system must allow for the output of data in both hard copy (printed) and electronic format (CD$\mathrm{ROM}$, online, Internet).

10. Cost: The system should be economical o run and maintain.

Harteveld and Louw (2004) advise that the steps indicated above should be a perquisite for any adaptation and use of software in the editorial process. It is important to consider these because the cost and time of customisation will depend on the type and complexity of the dictionary being compiled. The program that will be provided initially may be a generic platform and will need to 
be customised for each specific dictionary. New dictionaries may be created at a later stage and father customisation will then be required. The contract with the creators of the software must not only make provision for continued support of the software, but also for father customisation at minimal or no cost to the compilers. There must be training and support for the chosen tools, as well as a fixed period of familiarisation with the tools.

Computers have affected dictionaries in two major areas: production and research. On the production side, dictionaries can now be stored in databases, so that a change can be made very quickly and changes that affect the entire dictionary can be done in one-step. New editions of dictionaries can be produced without having to retypeset the entire work. Computers have already become important as a method for publishing dictionaries in electronic format instead of paper, and this will likely be increasingly important in the future.

For research, lexicographers can have instant access to corpora of the language and can thus look for example sentences of rare works, compare grammatical information, gather example sentences, and in general rely on real life examples of the language instead of having to fall back on personal impressions. They can also communicate rapidly with consultants across the world by using e-mail. It has become difficult for any lexicographic project to avoid the use of computers and all the tools that come along with it.

\section{Conclusion}

Dictionary making is a long, complex and time-consuming activity. As the work involved is vast, it is necessary that detailed planning be done before it begins. The compilation of every dictionary has to be preceded by the formulation of a lexicographic plan adhering to the aims of the typological criteria of that specific dictionary, and aimed at the specific needs and reference skills of a well-defined target user. This plan must not be done in a haphazard way, but has to be rooted in a general theory of lexicography.

According to Wiegand (1984: 14-15), one of the components of a general theory of lexicography is the theory of organisation. This includes all the activities leading to the drawing up of a plan that has to precede that compilation of every dictionary. There are some crucial issues to be considered for the lexicographic planning. For example, the planning cannot start without a decision about the type of dictionary because the macrostructure and the microstructure dictionary and a bilingual dictionary are different, and even more so in the case of school dictionary. The lexicographer should decide about the language of the dictionary, and the social and stylistic variations of the language. In this regard, all the structural components of a dictionary, including the macrostructure, microstructure, mediostructure and access structure come into play.

These decisions should be made before staring the actual work on the dictionary and should be strictly adhered to. All decisions must be printed and recorded to ensure continuity when new staff join the project. Instructions must 
be completed and detailed. A blueprint for the project, which may contain descriptions and instructions for the collection of material, which sources mentioned, the compilation of the word list, and the articles of the intended dictionary, is advisable. Besides these details, the project should reflect the scope of the dictionary, its purpose and the target user group. The preparation of such a blueprint will not only help as a guidebook for the compilers in which the data distribution is explained, but can also be used to prepare the front and back matter texts.

In view of revamping mother tongue education dictionary perspectives with the strategic planning of Gabonese lexicography, the present article has provided a tentative conceptual framework for the production of such specific dictionaries in Gabonese native languages. While it can be recognized that Gabonese lexicography has embarked itself in a fast-growing developing process, current dictionary projects in progress and recently published dictionaries in Gabonese languages do not show any purpose for mother tongue education. This article has pleaded for mother tongue education dictionary projects in Gabon.

\section{Notes}

1. Mr Guy Nzouba Ndama was Speaker of Gabonese National Assembly for 20 years, and is currently one of the main leaders of opposition in Gabon.

2. Woleu-Ntem province is the only province in Gabon that is about $90 \%$ monolingual. The regional language of the province is Fang, the mother tongue of the vast majority of the population of this. There are also in very limited numbers speakers of Hausa and Baka, which are also indigenous to the province, but they also speak Fang on a daily basis. WoleuNtem is also the only Gabonese province where Hausa and Baka can originally be found. Although a few varieties of Fang can be found in four other provinces of Gabon (Estuaire, Moyen-Ogooué, Ogooué-Ivindo and Ogooué-Maritime), the Fang spoken in Woleu-Ntem shows different dialectal variants. Every major town in Woleu-Ntem, i.e. Oyem, Bitam, Minvoul, Mitzic and Medouneu has its own variety of Fang.

\section{References}

\section{Dictionaries and Encyclopaedias}

Biton, A. 1907. Dictionnaire français-ndumu et ndumu-français, précédé d'éléments de grammaire. Nantes: Imprimerie Bourgeois.

Biton, A. and J.J. Adam. 1969. Dictionnaire Ndumu-Mbede-Français et Français-Ndumu-Mbede. Petite Flore de la Région de Franceville (Gabon). Grammaire Ndumu-Mbede. Archevêché de Libreville. Bar-le-Duc: Imprimerie St Paul.

ILALOK (Institut des Langues Locales au Kouilou). 2008. Dictionnaire Vili-Français/Mpisukulu Bi Kum' Bi Tshi Vili Ku Tshi Mputu. Paris: L'Harmattan.

Mavoungou, P.A. and B. Plumel. 2010. Dictionnaire yilumbu-français. Libreville: Éditions RapondaWalker. 
Mavoungou, P.A. and H.S. Ndinga-Koumba-Binza. Submitted. Dictionnaire des Expressions Idiomatiques Lumbu. Louvain/Paris: Éditions Peeters.

Mickala-Manfoumbi, R. 2004. Lixique Pove-Français. Français-Pove. Libreville: Éditions RapondaWalker.

Mickala-Manfoumbi, R. 2012. Dictionnaire des Noms Personnels Pove. Paris: Éditions Alpha-Omega.

Raponda-Walker, A. 1934. Dictionnaire Mpongzwè-Français, suivi d'Éléments de Grammaire. Metz: Imprimerie de la Libre Lorraine.

Van der Veen, L.J. and S. Bodinga-bwa-Bodinga. 2002. Gedandedi Sa Geviya. Dictionnaire GeviyaFrançais. Leuven/Paris/Sterling: Peeters.

\section{Other literature}

Afane Otsaga, T. 2004. The Standard Translation Dictionary as an Instrument in the Standardisation of Fang. Unpublished D.Litt. Dissertation. Stellenbosch: Stellenbosch University.

Afane Otsaga, T. 2010a. Alphabet et orthographe: critères, qualités, conditions et vulgarisation dans le cas du Gabon. Hubert, J. and P.A. Mavoungou (Eds.). 2010. Ecriture et Standardisation des Langues Gabonaises: 69-89.Stellenbosch: SUN PRESS.

Afane Otsaga, T. 2010b. Propositions pour l'orthographe du fang. Hubert, J. and P.A. Mavoungou (Eds.). 2010. Ecriture et Standardisation des Langues Gabonaises: 188-191. Stellenbosch: SUN PRESS.

Alberts, M. 1997. Lexicographic Needs Assessment. PanSALB Lexicographic Consultative Meeting, Johannesburg, 31 October 1997: 7-12.

Bergenholtz, H. 1990. Lexikographische Instruktionen für ein zweisprachiges Wörterbuch. Zeitschrift für Phonetik, Sprachwissenschaft und Kommunikationsforschung 43: 19-37.

Blanchon, J.A. 1984. Présentation du yi-lumbu dans ses rapports avec le yi-punu et le ci-vili à travers un conte traditionnel. Pholia 1: 7-35.

Blanchon, J.A. 1990. Civili. Revue Gabonaise des Sciences de l'Homme 2: 141-142.

Ekwa Ebanéga, G-M. 2007. A Microstructural Programme for Dictionaries in Fang. Unpublished D. Litt. Dissertation. Stellenbosch: Stellenbosch University.

Ella, E.M. 2002. Un dictionnaire scolaire de langue de spécialité. Emejulu, J.D. (Ed.). 2002. Éléments de Lexicographie Gabonaise. Tome 2: 305-325. New York: Jimacs-Hillman.

Ella, E.M. 2007. A Theoretical Model for a Fang-French-English Specialized Multi-volume School Dictionary. Unpublished D.Litt. Dissertation. Stellenbosch: Stellenbosch University.

Emejulu, J.D. 2001. Lexicographie multilingue et multisectorielle au Gabon: planification, stratégie et enjeux. Emejulu, J.D. (Ed.). 2001. Éléments de lexicographie gabonaise. Tome 1: 38-57. New York: Jimacs-Hillman.

Emejulu, J.D. 2003. Challenges and Promises of a Comprehensive Lexicography in the Developing World: The Case of Gabon. Botha, W.F. (Ed.). 2003. 'n Man wat beur. Huldingingsbundel vir Dirk van Schalkwyk: 195-212. Stellenbosch: Bureau of the WAT.

Emejulu, J.D. and F. Pambo Loueya. 1990. Yilumbu. Revue Gabonaise des Sciences de l'Homme 2: 197-201.

Gouws, R.H. 1997. Lexicographic Planning. PanSALB Lexicographic Consultative Meeting, Johannesburg, 31 October 1997: 16-20.

Gouws, R.H. 2001. Lexicographic Training: Approaches and Topics. Emejulu, J.D. (Ed.). 2001. Éléments de Lexicographie Gabonaise. Tome 1: 58-94. New York: Jimacs-Hillman. 
Harteveld, T. and P.A. Louw. 2004. Course on the Editing Tools in Dictionary Making. Stellenbosch: Bureau of the WAT.

Kwenzi Mikala, J.T. 1990. Quel avenir pour les langues gabonaises? Revue Gabonaise des Sciences de l'Homme 2: 121-124.

Kwenzi Mikala, J.T. 1998. Parlers du Gabon: classification du 11.12.97. Raponda-Walker, A. (Ed.). 1998. Les langues du Gabon: 217-221. Libreville: Éditions Raponda Walker.

Landau, S.I. 1984. Dictionaries: The Art and Craft of Lexicography. New York: The Scribner Press.

Loembe, G. 2008. Parlons Vili: Langue et Culture de Loango. Paris: L'Harmattan.

Mabika Mbokou, L. 1999. Les Phénomènes Analogiques en Civili: Étude Phonologique et Morphologique. Unpublished M.A. Thesis. Libreville: Omar Bongo University.

Mabika Mbokou, L. 2001. Le rôle du dictionnaire dans le système éducatif. Emejulu, J.D. (Ed.). 2001. Éléments de Lexicographie Gabonaise. Tome 1: 206-222. New York: Jimacs-Hillman.

Mabika Mbokou, L. 2006. A Model for the Macro- and Microstructure of a Yipunu-French School Dictionary. Unpublished D.Litt. Dissertation. Stellenbosch: Stellenbosch University.

Mavoungou, P.A. 2000. A Frequency List of the Yilumbu Language. Unpublished Study Conducted at the Bureau of the Woordeboek van die Afrikaanse Taal (WAT), Stellenbosch.

Mavoungou, P.A. 2002. Metalexicographical Criteria for the Compilation of a Trilingual Dictionary: Yilumbu-English-French. Unpublished D.Litt. Dissertation. Stellenbosch: Stellenbosch University.

Mavoungou, P.A. 2010. Lexicographie et confection des dictionnaires au Gabon. Stellenbosch: SUN PRESS.

Mavoungou, P.A. 2012. Towards a Yilumbu Dictionary of Idiomatic Phrases. Ndinga-KoumbaBinza, H.S. and S.E. Bosch (Eds.). 2012. Language Science and Language Technology in Africa: A Festschrift for Justus C. Roux: 177-198. Stellenbosch: SUN PRESS.

Mboumba, L.H. 2009. Quelques Problèmes Métalexicographiques en Yilumbu: Le Cas des Parties du Discours. M.A. Thesis. Libreville: University of Omar Bongo.

Mickala-Manfoumbi, R. 2013. Essai de Grammaire Pove. Paris: Éditions Alpha-Oméga.

Mihindou, G.-R. 2006. A Theoretical Model for a Yipunu-English-French Explanatory Dictionary of Medical Terms. Unpublished D.Litt. Dissertation. Stellenbosch: Stellenbosch University.

Ndinga-Koumba-Binza, H.S. 2000. Phonologie du Civili de Mayumba: Langue Bantu du Gabon (H12a). Unpublished M.A. Thesis. Libreville: University of Omar Bongo.

Ndinga-Koumba-Binza, H.S. 2005. Considering a Lexicographic Plan for Gabon within the Gabonese Language Landscape. Lexikos 15: 132-150.

Ndinga-Koumba-Binza, H.S. 2008. Phonetic and Phonological Aspects of the Civili Vowel Duration: An Experimental Approach. Unpublished D.Litt. Dissertation. Stellenbosch: University of Stellenbosch.

Ndinga-Koumba-Binza, H.S. 2017. Language and Dialects in Gabon: An Analysis of Languageunits towards Language Inventory. Prah, K.K. and L.M. Miti (Eds.). 2017. Deconstructing of the African Tower of Babel. Between the Harmonization and Fragmentation of African Language Orthographies. Cape Town: The Centre for Advanced Studies in the African Society.

Ndinga-Koumba-Binza, H.S. and L. Mabika Mbokou. 2010. Combined Corpus Project of Yipunu, Civili and Yilumbu. Paper presented at the Interim Conference of the African Language Association of Southern Africa (ALASA) held at the University of Botswana, Gaborone, Botswana, 21-23 July 2010.

Ndinga-Koumba-Binza, H.S., B. Nyangone Assam and V. Ompoussa. 2017. Perspectives for Lexicography Units in Multilingual Gabon. Paper presented at the 22nd International Conference of the African Association for Lexicography (AFRILEX) held at Rhodes University, Grahamstown, South Africa, 26-29 June 2017. 
Nyangone Assam, B. 2001. La lexicographie dans l'apprentissage des langues gabonaises. Emejulu, J.D. (Ed.). 2001. Éléments de Lexicographie Gabonaise. Tome 1: 187-205. New York: Jimacs-Hillman.

Nyangone Assam, B. 2002. Le dictionnaire pédagogique scolaire: quelques aspects du traitement lexicographique. Emejulu, J.D. (Ed.). 2002. Éléments de Lexicographie Gabonaise. Tome 2: 292304. New York: Jimacs-Hillman.

Nyangone Assam, B. 2006. Dictionaries as Teaching Instruments for Mother-tongue Education: The Case of Fang in Gabon. Unpublished D.Litt. Dissertation. Stellenbosch: Stellenbosch University.

Nyangone Assam, B., H.S. Ndinga-Koumba-Binza and V. Ompoussa. 2016. What French for Gabonese French Lexicography? Lexikos 26: 162-192.

Nzang-Bie, Y. 2001. Vers une éducation multilingue au Gabon: première approche. Revue Gabonaise des Sciences du Langage/Gabonese Journal of Language Sciences 2: 17-29.

République Gabonaise. 2010. Etats Généraux de l'Éducation, de la Recherche et de l'Adéquation Formation-Emploi. Les Actes Adoptés. Libreville, les 17 et 18 mai 2010. Libreville: Ministère de l'Éducation Nationale, de l'Enseignement Supérieur, de la Recherche Scientifique et de l'Innovation.

Samarin, W.J. 1967. Field Linguistics: A Guide to Linguistic Field Work. New York: Holt, Rinehart and Winston.

Saphou-Bivigat, G. 2010. A Theoretical Model for an Encyclopaedic Dictionary for the Gabonese Languages with Reference to Yilumbu. Unpublished D.Litt. Dissertation. Stellenbosch: Stellenbosch University.

Singh, R.A. 1982. An Introduction to Lexicography. Manasagangotri, Mysore: Central Institute of Indian Languages.

Soami, L.S. 2010. Towards the Development and Application of Representative Lexicographic Corpora for the Gabonese Languages. Ph.D. Thesis. Stellenbosch: Stellenbosch University.

Tele-Pemba, A.M. 2009. Eléments pour une Approche Comparée des Emprunts Lexicaux du civili du Gabon, du Congo-Brazzaville et du Cabinda: Proposition d'un Modèle de dictionnaire. M.A. Thesis. Libreville: University of Omar Bongo.

Tomba Moussavou, F. 2007. Metalexicographic Criteria for a Monolingual Descriptive Dictionary Presenting the Standard Variety of Yipunu. Ph.D. Thesis. Stellenbosch: Stellenbosch University.

Van Schalkwyk, D.J. 1999. Planning and Management — The Most Neglected Activities in Lexicography. Lexikos 9: 198-207.

Wiegand, H.E. 1984. On the Structure and Contents of a General Theory of Lexicography. Hartmann, R.R.K (Ed.). 1984. LEXeter '83 Proceedings. Papers from the International Conference on Lexicography at Exeter, 9-12 September 1983: 13-30. Lexicographica. Series Maior 1. Tübingen: Max Niemeyer Verlag.

Wiegand, H.E. 1998. Wörterbuchforschung. Untersuchungen zur Wörterbuchbenutzung, zur Theorie, Geschichte, Kritik und Automatisierung der Lexikographie. 1. Teilband. Mit 159 Illustrationen im Text. Berlin/New York: Walter de Gruyter.

Zgusta, L. 1971. Manual of Lexicography. Prague: Academia/The Hague/Paris: Mouton. 